\title{
ОРХОН ГОЛЫН УСНЫ ЧАНАРЫН СУДАЛГАА
}

\author{
Ч.Жавзан \\ ШУА-ийн Геоэкологийн хүрээлэн
}

\begin{abstract}
Orkhon is the longest river in Mongolia and most of its big tributaries flow through urbanized and industrialized areas. This situation increases the risk of water pollution by domestic wastes. Furthermore, due to the centralized mining activities in the Orkhon river basin and its downstream tributaries, the water quality is tend to decrease. The result of the study shows there is a tendency of elevated level of heavy metal in the sediment in the particular part of the river. Elevated level of heavy metal in the sediment therefore can lead to degradation of river ecosystem, however water quality become relatively good at the effluent of the Selenge River by its selfpurification ability. Therefore extended investigations are required and rehabilitation activities should be done.
\end{abstract}

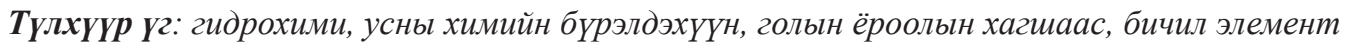

\section{ОРШИЛ}

Ус нь байгаль дээр бүрэлдэн тогтох явцдаа янз бүрийн бодисуудыг өөртөө уусгахын зэрэгцээ бичил биетүүдийг агуулсан байдаг. Өнөөгийн нийгэмд хүний болон байгалийн хүчин зүйлс байгалийн усны чанар, химийн бүрэлдэхүүнд төдийгүй усан орчны экосистемд төдийгүй амьтан ургамал, хүн төрөлхтөний хэвийн амьдралд сөрөг нөлөө Үзүүлэхээр болж байна.

Түүнчлэн онолын суурь судалгаанаас гадна ашиглалтын улмаас үүссэн экологийн өөрчлөлтийг судлах явдал улам бүр хэрэгцээ болж үүнтэй уялдан байгаль орчныг хамгаалах, байгалийн нөөц баялгийг зүй зохистой ашиглах, нөхөн сэргээхэд чиглэсэн судалгааны хүрээ өргөжиж мониторинг хяналтын шинэ систем нэвтэрч, судалгааны олон чиглэлийг ашиглах болсон.

Бид энэхүу өгүүлэлдээ Шинжлэх ухаан, технологийн сангийн санхүүжилтээр ШУАийн Геоэкологийн хүрээлэнд хэрэгжсэн төслүүдийн үр дүнг эмхэтгэн урд өмнө энэ чиглэлээр хийсэн судалгаатай харьцуулан оруулсан ба манай орны хамгийн урт гол болох Орхон гол, Хангал, Туул, Хараа, Шарын гол, Ерөө, Буур зэрэг цутгал голуудын усны чанарын талаар шинэхэн судалгааны дүнг үндэслэн өгүүлэх болно. Эдгээр голууд нь алтны үйлдвэрлэлийн болон ахуйн бохирдолд харьцангуй ихээр өртсөн учир Орхон голын усны чанар болоод усан орчны экологид сөрөг нөлөөтэй байна.

\section{СУДАЛГААНЫ АРГА ЗУЙ}

Орхон гол, түүний адаг хэсгийн цутгал голуудын сонгосон цэгүүдээс усны болон ёроолын хагшаасын дээж авч, усны шинж чанар, тэдгээрийн үзүүлэлтүүдийг усан дахь ууссан хий, ионуудын тэнцвэр алдагдах, органик бодисууд, бичил биетүүдийн задрал явагдахаас өмнө усны орчин $(\mathrm{pH})$, температур, цахилгаан дамжуулах чадар, ууссан хий (хүчилтөрөгч, нүүрсхүчлийн хий, хүхэрт устөрөгч), шүлтлэг чанар, булингаршил гэх мэт амархан хувирамтгай үзүүлэлтүүдийг газар дээр нь тодорхойлж, харин үндсэн элементүүдийг суурин лабораторит орчин үеийн арга аргачлалаар 
батлагдсан стандартын дагуу задлан шинжилгээг хийв. Үүнд:

- Усны орчинг - Thermo Orion 290 зөөврийн $\mathrm{pH}$ метр, Thermo Orion 370 лабораторийн $\mathrm{pH}$ метрээр

- Температур, ууссан хүчилтөрөгчийг YSI 52 DO метр, Hach Multiparameter, VVR photometer болон Винклерийн аргаap

- Цахилгаан дамжуулах чанарыг Symphony VWR SP40C conductivity, Hach Multiparameter

- Жинлэгдэгч бодис-Жингийн аргаар

- Сульфатын ион- Жингийн болон эзэлхүүний аргаар

- $\mathrm{Ca}$; $\mathrm{Mg}$; CO3; $\mathrm{HCO}$; $\mathrm{Cl}$; ПИЧ-титрийн аргаaр

- $\quad C N^{-}$- титрийн аргаар

- $\quad T N, T P, C O D, C d, P b, C u, C N$, total $C r$, $\mathrm{NH}_{4}^{+}, \mathrm{NO}_{2}^{-}, \mathrm{NO}_{3}^{-}$- Hach DR2800 portable Spectrophotometer болон T-60. UV-Vis Spectrophotometer багажууд дээр хэмжин тодорхойлно.

- Усны болон ёроолын хагшаасын хүнд металлыг УСУГ-ын Усны төв лаборатори болон бусад лабораториудад шинжлүүлсэн болно. Ёроольын

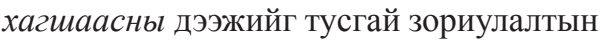
дээж авагчаар авч, лабораторийн нөхцөлд хатааж, шигшиж жигнээд механик бүрэлдэхүүнийг тодорхойлов. 1 мм-ийн шигшүурээр гарсан дээжинд ICP багажаар /УСУГ-ийн лабораторт/ хүнд металлын агууламжийг тодорхойлсон.

Судалгаанд хамрагдсан голуудын урд өмнө хийсэн шинжилгээний дүн, материалуудыг аль болох өргөн хэмжээнд цуглуулж, боловсруулалт хийж үнэлгээг өгөхдөө манай улсад мөрдөж буй стандарт, нормуудтай харьцуулав. Үүнд: Голын усны чанарыг үнэлэхдээ "Усан орчны чанарын Үзүүлэлт MNS 4586-98” стандарт болон Гадаргын усны цэврийн зэргийн ангилалын норм (ГУЦЗАН)-оор

- І анги - маш цэвэр ус

- II анги - цэвэр ус

- $\quad$ III анги - бага хэмжээгээр бохирдсон ус

- IY анги - бохирдсон ус

- Ү анги - их бохирдсон ус

- YI анги - маш их бохирдсон ус гэж ангилав.

Харин голын ёроолын хагшаасанд агуулагдах хүнд металлын зөвшөөрөгдөх дээд хэмжээг заасан стандарт норм манай улсад байхгүй учир усны чанарыг үнэлэхэд хүндрэлтэй байна. Иймд бид Герман улсын судлаачдын Элба мөрний жишээн дээр гаргасан "Гадаргын усны ёроолын хурдсанд агуулагдах хүнд металлын бохирдлын зэрэглэл”-ийг ашиглав[9].

Хуснэгт 1

Микроэлементийн агууламжийг зэрэглэсэн Мюллерийн ангилал, мг/кг

\begin{tabular}{|c|r|r|r|r|r|r|r|r|}
\hline Ангилал & \multicolumn{1}{|c|}{$\mathbf{A s}$} & $\mathbf{C d}$ & $\mathbf{C r}$ & $\mathbf{P b}$ & $\mathbf{H g}$ & $\mathbf{N i}$ & $\mathbf{Z n}$ & $\mathbf{C u}$ \\
\hline 0 & 0.0195 & 0.00045 & 0.135 & 0.030 & 0.0006 & 0.102 & 0.1425 & 0.0675 \\
\hline 1 & 0.039 & 0.0009 & 0.270 & 0.060 & 0.0012 & 0.204 & 0.285 & 0.135 \\
\hline 2 & 0.078 & 0.0018 & 0.540 & 0.120 & 0.0024 & 0.408 & 0.570 & 0.270 \\
\hline 3 & 0.156 & 0.0036 & 1.080 & 0.240 & 0.0048 & 0.816 & 1.140 & 0.540 \\
\hline 4 & 0.312 & 0.0072 & 2.160 & 0.480 & 0.0096 & 1.632 & 2.280 & 1.080 \\
\hline 5 & 0.624 & 0.0144 & 4.320 & 0.960 & 0.0192 & 3.264 & 4.560 & 2.160 \\
\hline
\end{tabular}

Гадаргын усыг химийн бүрэлдэхүүний хувьд ангилахдаa дараах зарчмыг баримтлана. Үүнд: Анионы зонхилох байдлаар нь 1 ба 2-р зонхилогч ионыг хооронд нь ялгаж 50 мг-экв/\%-иас дээшхийг нэгдүгээр, харин нэгдүгээрээс 10 мг-экв/\%иас багагүй хэмжээгээр найрлаганд нь оролцсон ионуудыг дараачийн зонхилогчид тооцож дараах ангид хувааж үздэг. Үүнд:

- $\mathbf{H C O}_{3}$ (гидрокарбонатын ангийн усанд эрдэсжилт багатай, гол, мөрөн, нуур, газрын доорх цэнгэг ус орно)

- $\mathbf{S O}_{4}$ (сульфатын ангид гидрокарбонат ба хлорын ангийн завсрын шинж чанарыг хадгалсан бүх төрлийн ус орно) 
- $\mathbf{C l}$ (хлорын ангийн усанд тэнгис далайн болон эрдэсжилт ихтэй газрын доорх ус ихэвчлэн орно)

Мөн үүнээс гадна эдгээр ионуудын хоорондын харьцаа маш ойрхон (10 мг-экв \%-иас бага) байвал холимог ангид тооцдог. Харин катионоор нь кальцийн, магнийн, натрийн, холимог гэсэн 4 бүлэгт хуваадаг бөгөөд анион, катионы харгалзах байдлаар нь дараах төрөлд хуваадаг. Үүнд:

- $\mathrm{HCO}_{3}^{-}>\mathrm{Ca}^{++}+\mathrm{Mg}^{++}$мг-экв/дм ${ }^{3}-1-\mathrm{p}$ төрлийн ус

$-\mathrm{HCO}_{3}^{-}<\mathrm{Ca}^{++}+\mathrm{Mg}^{++}<\mathrm{HCO}_{3}^{-}+\mathrm{SO}_{4}^{-}$ мг-экв/дм ${ }^{3}$ - 2-р төрлийн ус

$-\mathrm{HCO}_{3}^{-}+\mathrm{SO}_{4}^{--}<\mathrm{Ca}^{++}+\mathrm{Mg}^{++}$мг-экв/дм ${ }^{3}$

- 3-р төрлийн ус

- $\mathrm{HCO}_{3}^{-}=0$ бол 4-р төрлийн ус байна.

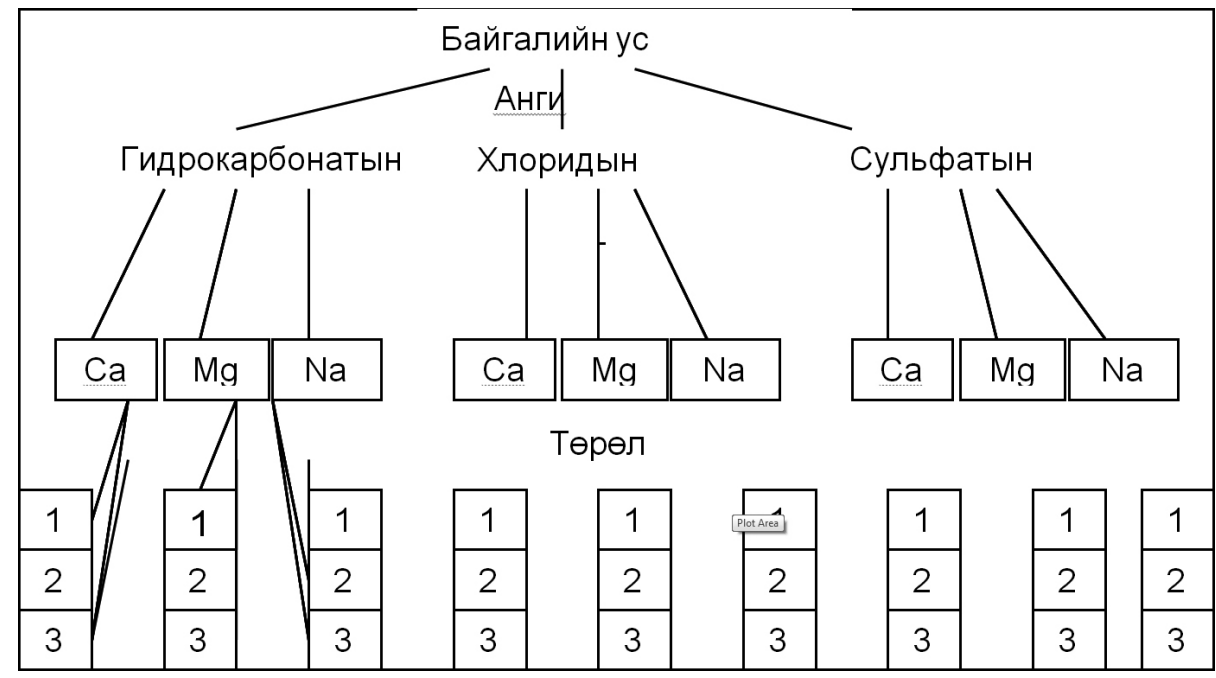

Зураг 1. Байгалийн усны ангилал (О.А.Алекиныхаар)

Байгалийн усыг эрдэсжилтээр нь ангилсан олон ангилал байдгаас А.М.Овчинниковын ангиллыг ерөнхийд нь баримтлан унд, ахуйн болон малын усны нормыг харгалзан бид дараах байдлаар ангилдаг. Үүнийг хүснэгтээр үзүүлбэл:

Хуснэгт 2

Байгалийн усны эрдэсжилтийн ангилал

\begin{tabular}{|c|c|c|}
\hline І/д & Эрдәсекилтийн зэрэг & Эрдәсенилт, г/дм \\
\hline 1 & Нэн цэнгэг буюу ялимгүй эрдэсжилттэй & $<0.20$ \\
\hline 2 & ЦЦэнгэг буюу дунд зэргийн эрдэсжилттэй & $0.21-0.50$ \\
\hline 3 & Цэнгэгдүү буюу харьцангуй ихэвтэр эрдэсжилттэй & $0.51-1.00$ \\
\hline 4 & Давсархаг буюу их эрдэсжилттэй & $1.01-3.00$ \\
\hline 5 & Давстай буюу шорвогдуу & $3.01-7.00$ \\
\hline 6 & Их давстай буюу шорвог & $>7.01$ \\
\hline
\end{tabular}

Байгалийн усыг хатуулгаар нь ангилсан мөн л олон ангилал байдгаас Оросын эрдэмтэн, гидрохимич О.А.Алекины ангиллыг ерөнхийд нь баримтлан бид өөрийн орны стандарттай харьцуулан дараах байдлаар ангилан үздэг. 
Байгалийн усны хатуулгийн ангилал

\begin{tabular}{|c|l|c|}
\hline$д / д$ & \multicolumn{1}{|c|}{ Хатуллийн 3эрэг } & $<1.50$ \\
\hline 1 & Маш зөөлөн & $1.51-3.00$ \\
\hline 2 & Зөөлөн & $3.01-5.00$ \\
\hline 3 & Зөөлөвтөр & $5.01-7.00$ \\
\hline 4 & Хатуувтар & $7.01-9.00$ \\
\hline 5 & Хатуу & $>9.01$ \\
\hline 6 & Маш хатуу \\
\hline
\end{tabular}

Ийнхүу арга зүйгээр бид Орхон түүний төгсгөл хэсгийн томоохон цутгал голуудын усны чанар, найрлага, бохирдлын өнөөгийн байдалд үнэлгээ өгч, бохирдуулагч эх үүсвэрүүдийг тодорхойлж, цаашид авч хэрэгжүүлэх арга хэмжээний талаар өөрсдийн саналыг оруулж байна.

\section{СУДАЛГААНЫ ҮР ДҮН}

Орхон гол нь Архангай аймгийн Цэнхэр сумын нутаг Суварга хайрхан уулнаас эхтэй бөгөөд Архангай, Өвөрхангай, Булган, Сэлэнгэ аймгуудын нутгаар дайран өнгөрч хилийн наана (Сүхбаатар сумын төв) Сэлэнгэ мөрөнд цутгадаг. Олон жилийн судалгаагаар Орхон голын сав газрын голуудын усны эрдэсжилт ерөнхийдээ маш бага $(50-300$ мг/дм³ $)$ буюу нэн цэнгэгээс цэнгэг, хатуулгийн хувьд ихэвчлэн маш зөөлнөөс зөөлөвтөр устай [1].

Голын усны ионы бүтцэд анионоос гидрокарбонат $\left(\mathrm{HCO}_{3}^{-}\right)$дангаараа зонхилж, анионы харьцаа $\mathrm{HCO}_{3}>\mathrm{SO}_{4}{ }^{2-}$ $>\mathrm{Cl}^{-}$, катионы харьцаа $\mathrm{Ca}^{2+}>\mathrm{Na}^{+}+\mathrm{K}^{+}>\mathrm{Mg}^{2+}$, $\mathrm{Na}^{+}+\mathrm{K}^{+}>\mathrm{Ca}^{2+}>\mathrm{Mg}^{2+}$ байна. Орхон голын эхэн хэсгийн цутгал голууд (Өлт голын хөндий дэх жижиг голуудаас бусад) нь байгалийнхаа унаган төрхөөрөө байгаа цэвэр, тунгалаг, уулын цэнгэг голууд бөгөөд Орхон голын дунд хэсгээс эхлэн адаг руугаа хот суурин, үйлдвэр уурхай, хүний үйл ажиллагаанд өртсөн манай орны харьцангуй их бохирдолттой Хангал, Туул, Хараа, Шарын гол, Ерөө, Буур зэрэг голууд цутгадаг учир Орхон голын усны чанарт тодорхой хэмжээгээр сөргөөр нөлөөлдөг.

Орхон голд цутгадаг голуудын усны шинж чанараас шалтгаалан голын усны чанар уртынхаа дагууд өөрчлөгддөг байна.

Орхон гольнн уртылн дагуух усны чанар, химийн найрлага, 2005-2010 он

\begin{tabular}{|c|c|c|c|c|c|c|c|c|}
\hline \multirow[b]{2}{*}{ Дээж авсан цэгүүд } & \multirow{2}{*}{$\begin{array}{l}\sum_{\text {ион }} \\
M г / \partial M^{3}\end{array}$} & \multirow{2}{*}{ 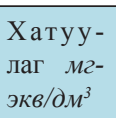 } & \multicolumn{6}{|c|}{ Гол ионууд, мг/дм ${ }^{3}$} \\
\hline & & & $\mathrm{Ca}^{2+}$ & $\mathrm{Mg}^{2+}$ & $\begin{array}{l}\mathrm{Na}^{+}+ \\
\mathrm{K}^{+}\end{array}$ & $\mathrm{HCO}_{3}^{-}$ & $\mathrm{SO}_{4}^{2-}$ & $\mathrm{Cl}^{-}$ \\
\hline $\begin{array}{l}\text { Орхон гол, Улаан гол } \\
\text { нийлэхийн өмнө (Өвөрхангай, } \\
\text { Бат Өлзий) }\end{array}$ & 148.7 & 1.00 & 18.0 & 1.2 & 20.9 & 91.5 & 10.0 & 7.1 \\
\hline $\begin{array}{l}\text { Орхон гол, Өвөрхангай, } \\
\text { Хархорин сум }\end{array}$ & 167.3 & 1.75 & 22.0 & 7.9 & 10.0 & 109.8 & 10.0 & 7.1 \\
\hline \multirow{2}{*}{$\begin{array}{l}\text { Орхон гол, Хангал гол } \\
\text { нийлэхийн өмнө (Булганы } \\
\text { Орхон сум) }\end{array}$} & 263.6 & 2.25 & 30.1 & 9.1 & 35.5 & 131.2 & 18.9 & 8.9 \\
\hline & 190.6 & 1.85 & 27.1 & 6.1 & 15.4 & 122.0 & 13.0 & 7.1 \\
\hline $\begin{array}{l}\text { Орхон гол, Туул гол нийлэхийн } \\
\text { өмнө (Орхон, Жаргалант сум) }\end{array}$ & 240.7 & 2.45 & 36.1 & 7.9 & 16.0 & 161.6 & 12.0 & 7.1 \\
\hline \multirow{2}{*}{$\begin{array}{l}\text { Орхон гол, Орхоны гүүр } \\
\text { (Сэлэнгэ, Сант сум) }\end{array}$} & 244.6 & 2.60 & 38.1 & 8.5 & 14.2 & 160.1 & 13.0 & 10.7 \\
\hline & 208.6 & 2.00 & 26.1 & 8.5 & 18.0 & 134.2 & 11.0 & 10.7 \\
\hline \multirow{3}{*}{$\begin{array}{l}\text { Орхон гол, Хараа нийлэхийн } \\
\text { өмнө (Дархан-Уул, Орхон сум) }\end{array}$} & 238.7 & 2.45 & 32.1 & 10.3 & 16.4 & 155.6 & 10.0 & 14.2 \\
\hline & 283.5 & 2.40 & 36.1 & 7.3 & 35.6 & 167.5 & 12.0 & 24.9 \\
\hline & 266.2 & 2.80 & 40.1 & 9.7 & 18.9 & 170.6 & 16.0 & 10.7 \\
\hline
\end{tabular}




\begin{tabular}{|c|c|c|c|c|c|c|c|c|}
\hline \multirow{3}{*}{$\begin{array}{l}\text { Орхон гол, Шарын гол } \\
\text { нийлэхийн өмнө (Дархан-Уул, } \\
\text { Орхон сум) }\end{array}$} & 285.8 & 2.50 & 33.1 & 10.3 & 28.3 & 186.1 & 13.0 & 14.2 \\
\hline & 286.0 & 3.20 & 40.1 & 14.6 & 19.4 & 173.6 & 15.0 & 21.3 \\
\hline & 296.2 & 2.40 & 32.1 & 9.7 & 37.3 & 190.8 & 20.0 & 14.2 \\
\hline \multirow{3}{*}{$\begin{array}{l}\text { Орхон гол, Ерөө гол } \\
\text { нийлэхийн өмнө (Сэлэнгэ, } \\
\text { Шаамар сум) }\end{array}$} & 286.2 & 2.85 & 35.1 & 13.4 & 22.0 & 189.1 & 10.0 & 10.7 \\
\hline & 300.1 & 3.30 & 42.1 & 14.6 & 19.2 & 192.0 & 16.0 & 16.0 \\
\hline & 305.2 & 2.60 & 36.1 & 9.7 & 32.6 & 189.0 & 28.0 & 7.1 \\
\hline \multirow{3}{*}{$\begin{array}{l}\text { Орхон гол, Ерөө гол нийлсний } \\
\text { дараа (Сэлэнгэ, Шаамар сум) }\end{array}$} & 126,4 & 1,20 & 17,0 & 4,3 & 10,6 & 79,3 & 8,0 & 7,1 \\
\hline & 189.6 & 1.80 & 24.0 & 7.3 & 17.4 & 112.8 & 17.0 & 10.7 \\
\hline & 160.4 & 1.60 & 20.0 & 7.3 & 12.4 & 97.6 & 9.8 & 10.7 \\
\hline \multirow{2}{*}{$\begin{array}{l}\text { Орхон гол, Сэлэнгэд нийлэхийн } \\
\text { өмнө (Сэлэнгэ, Сүхбаатар) }\end{array}$} & 175.6 & 1.80 & 22.0 & 8.5 & 12.5 & 109.8 & 12.0 & 10.7 \\
\hline & 183.4 & 1.95 & 21.0 & 10.9 & 12.2 & 115.9 & 16.0 & 7.1 \\
\hline
\end{tabular}

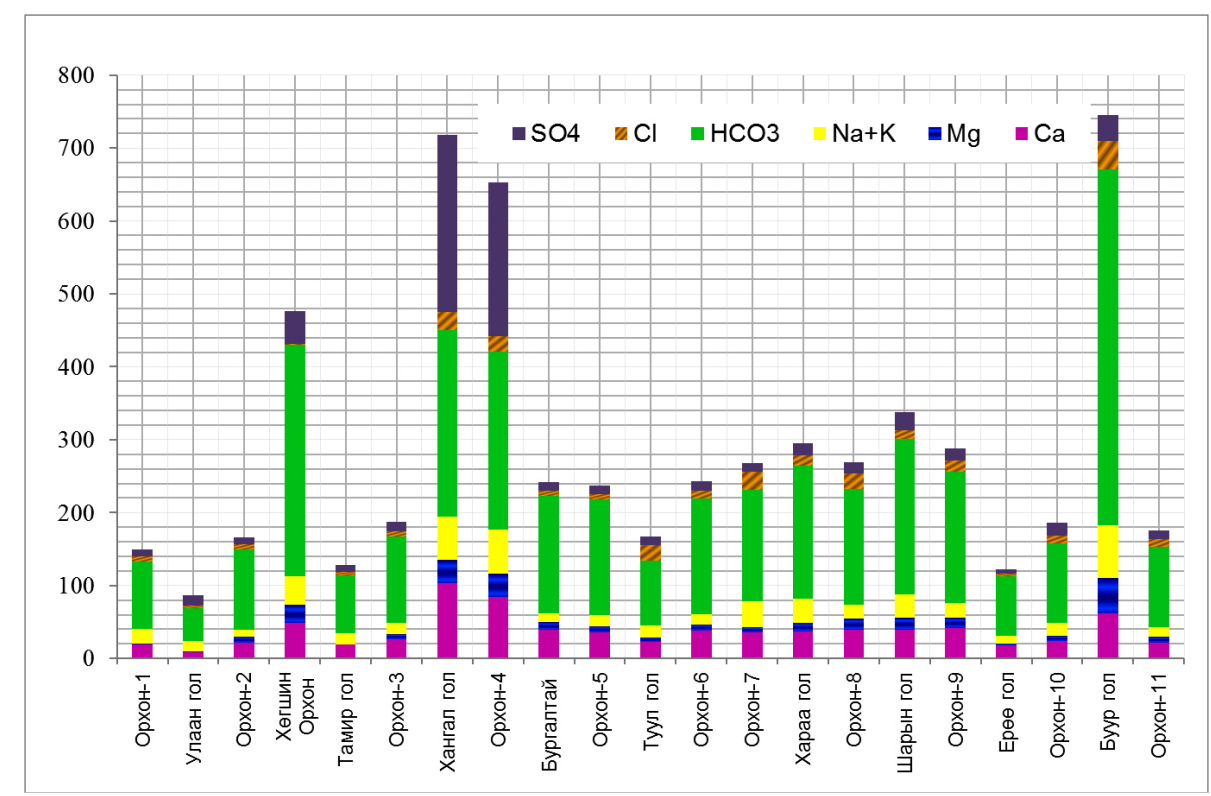

Зураг 2. Орхон гол, түҮний томоохон иутгалуудын усны эрдэсжилт, гол ионууд

Тайлбар: 1. Орхон-1. Улаан гол нийлэхээс өмнө; 2. Улаан гол, Орхон голд нийлэхээс өмнө; 3. Орхон-2, Хархорины услалтын системийн толгойн барилга; 4. Хөгшин Орхон гол, Хар хорин; 5. Тамир гол; 6. Орхон-3, Орхон сум, Хангал гол нийлэхээс дээш; 7. Хангал гол, Орхон голд нийлэхээс өмнө; 8. Орхон-4, Хангал гол нийлснээс доои 500м; 9. Бургалтай гол, Баруунбүрэн; 10. Орхон-5, Туул гол нийлэхийн өмнө; 11. Туул гол, Орхон голд нийлэхийн өмнө; 12. Орхон-6, Орхоны гүҮр; 13. Орхон-7, Хараа гол нийлэхийн өмнө; 14. Хараа гол, Орхон голд нийлэхийн өмнө; 15. Орхон-8, Хараа гол нийлсэн хэсэг; 16. Шарын гол, Орхон голд нийлэхээс өмнө; 17. Орхон-9, Шарын гол нийлснээс доош; 18. Ерөө гол, Дулаанхааны урдаас; 19. Орхон-10, Ерөө гол нийлснээс доош; 20. Буур гол, Сүхбаатар сум 21. Орхон-11, Орхон гол Сэлэнгэ мөрөнд иутгахаас өмнө.

Зургаaс харахад Орхон голын цутгал голуудын эхэн хэсгээс Улаан гол, дунд хэсгээс Тамир гол, адаг хэсгээс Ерөө гол хамгийн бага эрдэсжилттэй, харин дунд хэсгээс Хөгшин Орхон, адаг хэсгээс Хангал, Буур зэрэг голын ус хамгийн өндөр эрдэсжилттэй байгаа бөгөөд Хангал голын усны сульфатын ион харьцангуй их агууламжтай байна. Орхон голын усны эрдэсжилт, хатуулгийн хэмжээ урсгалынхаа дагуу нэмэгдэж (Хангал гол нийлсний дараа огцом өссөн) байснаа маш цэнгэг, их устай Ерөө гол (эрдэсжилт 70-110 мг/дм³, хатуулаг 0.70-1.00 мг-экв/дм ${ }^{3}$ ) нийлсний дараа түүний эрдэсжилт буурч, ихэнхдээ 200 мг/дм ${ }^{3}$ хүрэхгүй, нэн цэнгэг, зөөлөн устай болж Сэлэнгэд нийлж байна.

Орхон голын адаг хэсгийн ижил цэгүүд дээр (зуны улиралд авсан) үе үеийн судлаачдын хийсэн шинжилгээний дүнг эмхэтгэн дараах хүснэгтэд үзүүлэв. 
Орхон гольен адаг орчмын уснь химийн найрлага

\begin{tabular}{|c|c|c|c|c|c|c|c|c|c|}
\hline \multirow{2}{*}{$\begin{array}{c}\text { Шинжилсэн } \\
\text { хугацаа }\end{array}$} & \multirow{2}{*}{$\sum_{\text {мг/дон }}$} & \multirow{2}{*}{$\begin{array}{c}\text { Хатуулаг, } \\
\text { мг-экв/дм }{ }^{3}\end{array}$} & \multirow{2}{*}{$\mathrm{pH}$} & \multicolumn{6}{|c|}{ Гол ионууд, мг/дм³ } \\
\hline & & & & $\mathrm{Ca}^{2+}$ & $\mathrm{Mg}^{2+}$ & $\mathrm{Na}^{+}+\mathrm{K}^{+}$ & $\mathrm{HCO}_{3}^{-}$ & $\mathrm{SO}_{4}^{2-}$ & $\mathrm{Cl}^{-}$ \\
\hline 1973.07.16 & 191.1 & 1.32 & 8.10 & 20.6 & 3.4 & 17.3 & 122.0 & 20.2 & 7.8 \\
\hline 1974.08 .12 & 210.9 & 2.93 & 7.90 & 22.6 & 9.3 & 27.0 & 107.4 & 38.7 & 5.9 \\
\hline 1975.05 .20 & 192.5 & 2.00 & 8.00 & 24.0 & 5.0 & 20.9 & 128.1 & 10.0 & 5.6 \\
\hline $2002.07-08$ & 185.7 & 1.80 & 7.60 & 24.0 & 7.2 & 30.9 & 100.0 & 5.2 & 18.4 \\
\hline 2006.05 .25 & 175.6 & 1.80 & 8.00 & 22.0 & 8.5 & 12.5 & 109.8 & 12.0 & 10.7 \\
\hline 2010.08 .28 & 183.4 & 1.95 & 8.40 & 21.0 & 10.9 & 12.2 & 115.9 & 16.0 & 7.1 \\
\hline
\end{tabular}

Хүснэгтээс харахад олон жилийн хугацаанд Орхон голын усны эрдэсжилт, хатуулаг болон үндсэн элементүүдийн агууламжид онцгой өөрчлөлт ороогүй байна.

2006 оноос хойш бидний хийсэн хэмжилт судалгаагаар Орхон гол Сэлэнгэ мөрөнд цутгахын өмнө гидрокарбонатын ангийн, кальцийн бүлгийн, 1-р төрлийн устай, анионоос гидрокарбонат $\left(\mathrm{HCO}_{3}^{-}\right)$ дангаараа зонхилж, анионы харьцаа

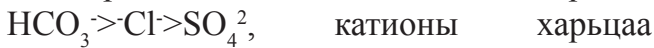
$\mathrm{Ca}^{2+}>\mathrm{Mg}^{2+}>\mathrm{Na}^{+}+\mathrm{K}^{+} \quad$ байна. Чанарын хувьд эрдэсжилт нь дунджаар 175.6 мг/ дм $^{3}$, хатуулаг 1.8 мг-экв/дм³, жинлэгдэгч бодисын хэмжээгээрээ гадаргын усны цэврийн зэргийн ангиллын норм ГУЦЗАНоор “Бага зэрэг бохирдолттой” гэсэн ангид орж байна[2].

Орхон голын усны микро элементүүдйн судалгааг ШУА-ийн
Геоэкологийн хүрээлэнгийн судлаачид дангаараа болон Олон улсын судалгааны багтай хамтран хийсэн. Усанд хүнд металлуудын хуримтлал үүсэх нь ихэвчлэн уул уурхайн үйлдвэрлэлийн үйл ажиллагаатай холбоотой байна.

Бичил элементүүд буюухүндметаллууд нь аливаа ордын дагалдах элемент болж газрын гүнд үүсээд, тухайн газрыг ухаж хөндөх үед газрын гадаргад ил гарч ирснээрээ химийн урвал, исэлдэн ангижрах процесст орж хувиран өөрчлөгдөж, орчныхоо хөрс, усанд нөлөөлдөг байна. Гадны нөлөөллийн улмаас гадаргын усанд үүссэн хүнд металлууд урсгалынхаа дагуу зөөвөрлөгдөх замдаa ёроолын хагшааст хуримтлагдаж байна. Энэ ч утгаараа бид уснаас гадна ёроолын хагшаасны дээж авч хатааж шигшээд, ICP багажаар хүнд металлуудыг тодорхойлсон [4].

Орхон гольнн уртын дагуух усан дахь бичил элементүҮдийн агууламж, мг/дм

\begin{tabular}{|c|c|c|c|c|c|c|c|c|c|c|c|c|}
\hline $\begin{array}{c}\text { Дээж авсан } \\
\text { цэгүҮд }\end{array}$ & $\mathrm{Cr}$ & $\mathrm{Mn}$ & $\mathrm{Fe}$ & $\mathrm{Co}$ & $\mathrm{Ni}$ & $\mathrm{Cu}$ & $\mathrm{Zn}$ & As & $\mathrm{Cd}$ & $\mathrm{Pb}$ & $\mathrm{Ag}$ & Mo \\
\hline \multicolumn{13}{|c|}{ ОХУ-ын Буриадын Байгалийн нөөцийн хүрээлэнгийн дүн, 2002} \\
\hline Орхон (дунд) & 0.0057 & & & 0 & 0 & 0.0843 & 0 & & 0.0009 & 0.0125 & & \\
\hline Орхон (адаг) & 0.0044 & & & 0.0050 & 0.0002 & 0.0281 & 0 & & 0.0016 & 0.0195 & & \\
\hline \multicolumn{13}{|c|}{ БНСУ-ын Байгалийн нөөцийн хүрээлэнгийн дүн, 2009} \\
\hline Орхон (эхэн) & 0.0005 & 0.0051 & 0.0799 & 0.0001 & 0.0010 & 0.0015 & 0.0222 & 0.0074 & үл мэдэг & 0.0005 & & \\
\hline Орхон (дунд) & 0.0028 & 0.0236 & 0.427 & 0.0009 & 0.0042 & 0.0026 & 0.1131 & 0.0125 & үл мэдэг & 0.0004 & & \\
\hline Орхон (адаг) & 0.0005 & 0.0183 & 0.8802 & & 0.0007 & 0.0006 & 0.0154 & 0.0014 & үл мэдэг & & & \\
\hline \multicolumn{13}{|c|}{ Геоэкологийн хүрээлэн (УСУГ-ын лаборатори), 2011} \\
\hline $\begin{array}{l}\text { Орхон (Хараа } \\
\text { гол нийлэхийн } \\
\text { өмнө) }\end{array}$ & 0 & 0 & 0.0146 & 0.001 & 0.001 & 0.006 & 0 & 0.001 & 0 & 0 & 0.006 & 0.012 \\
\hline $\begin{array}{l}\text { Орхон (Ерөө } \\
\text { гол нийлсний } \\
\text { дараа) }\end{array}$ & 0 & 0 & 0.1744 & 0 & 0.001 & 0.006 & 0.014 & 0 & 0 & 0.001 & 0.012 & 0.001 \\
\hline
\end{tabular}


Орхон гол, түүний адаг хэсгийн цутгал голуудын усны болон ёроолын хагшааснаас

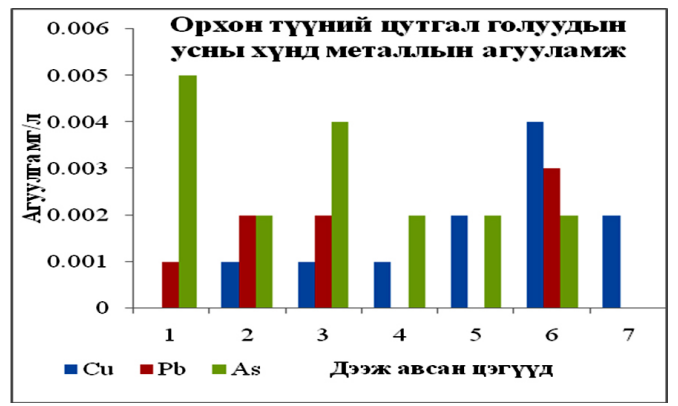

2010 онд авсан дээжинд бичил элементүүд шинжилсэн дүнг графикаар үзүүлэв.

Зураг 3. Орхон, түүний иутгал голуудын усны хүнд металлын агууламж

Дээж авсан иээүүд: 1.Орхон гол, Хараа гол нийлэхийн өмнөх 2. Хараа гол, Орхонд нийлэхийн өмнө 3.Орхон гол, Хараа гол нийлсний дараа 4. Шарын гол, Орхонд нийлэхийн өмнө 5.Орхон гол, Шарын гол нийлсний дараа 6. Ерөө гол, Орхонд нийлэхийн өмнө 7. Орхон гол, Ерөө гол нийлсний дараа
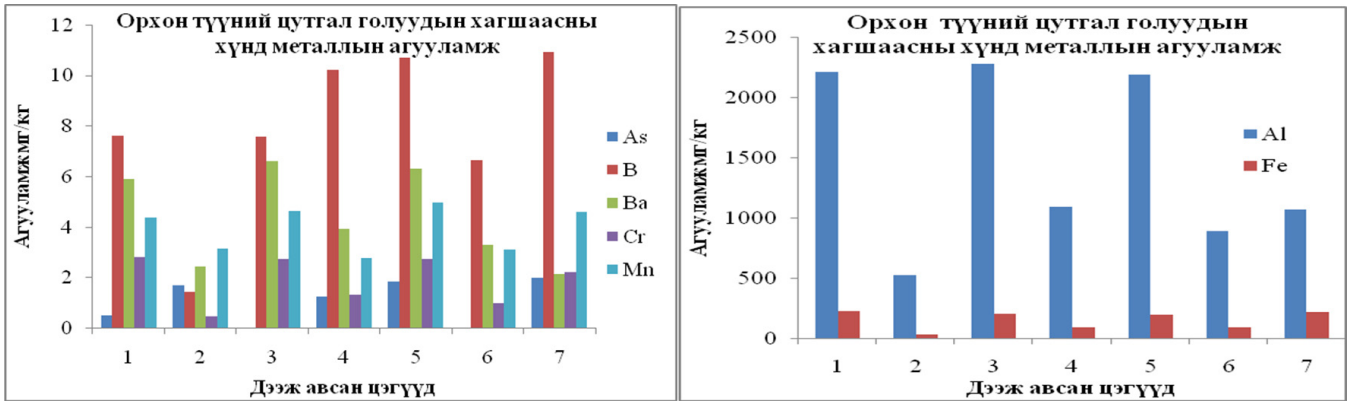

Зураг 4. Орхон, түүний иутгал голуудын хагшаасан дахь хүнд металльн агууламж

Орхон, түүний цутгал голуудын усанд бичил элементүүдийн агууламж тодорхойлсон дүнгээс үзэхэд Ерөө голын усанд хөнгөн цагаан, төмрийн агууламж харьцангуй өндөр гарсан байна. Эдгээр элементүүд нь газрын давхаргын үндсэн элемент бөгөөд уул уурхайн үйлдвэрлэлийн үйл ажиллагаанаас усанд булингар (коллойд) хэлбэрээр орж, урсгалын явцад ёроолын хагшааст хуримтлагддаг байна. Иймээс ч голын ёроолын хагшааст эдгээр элементүүдийн агууламж маш өндөр гарч байна. Ийнхүу Орхон болон түүний адаг хэсгийн цутгал голуудын усны бохирдол нь антропоген үйл ажиллагаатай шууд холбоотой байна.

Орхон гольин адаг хэсгийн иутгалуудылн усньл чанар

Орхон голын томоохон цутгал болох Туул гол нь экологийн өөрчлөлтөд нилээд

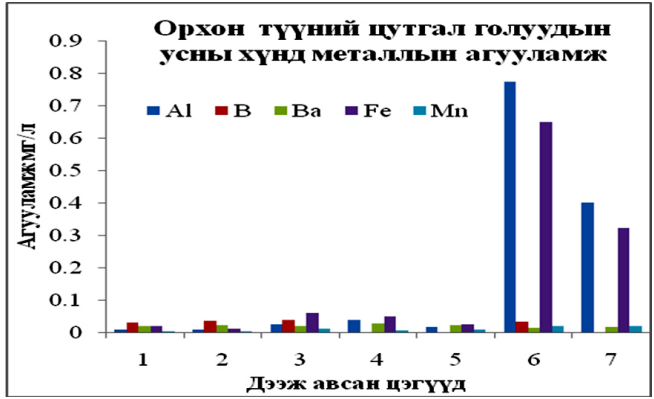


зарим саруудад химийн бүрэлдэхүүн өөрчлөгдөн сульфатын ион давамгайлах тохиолдол гарч байсны гадна ихэнх тохиолдолд усанд агуулагдах макро, микро, биоидэвхит элементүүдийн агууламж бүгд ихэсч Орхон гол химийн бохирдолтод ордог байна[7]. Эрдэнэт хотын урдуур урсах Эрдэнэт гол (17.6 км урт), зүүн талын Говил гол (15.5 км урт), зүүн хойд талын (одоо Уулын баяжуулах үйлдвэрийн хаягдлын нуур байгаa) Зуны гол нийлж Хангал голыг үүсгэдэг ба 70 гаруй км урсаад Орхон голын зүүн гараас цутгадаг. Уулын баяжуулах Эрдэнэт үйлдвэр үйл ажиллагаа явуулахаас өмнөх судалгаагаар эндэхийн голын усны эрдэсжилт улирлын байдлаас хамаарч өөрчлөгдөж Эрдэнэт гол усны эрдэсжилт 519-829 мг/дм³, хатуулаг 6.96-7.20 мг-экв/дм³, Говил голын усны дундаж эрдэсжилт 503 мг/дм³ , хатуулаг 7.89 мг-экв/дм ${ }^{3}$, Зуны голын эрдэсжилт 372 мг/ дм $^{3}$, хатуулаг 4.60 мг-экв/дм³ ${ }^{3}$ харин Хангал голын эрдэсжилт 585 мг/дм ${ }^{3}$, хатуулаг 5.44 мг-экв/дм ${ }^{3}$ байжээ. Эндээс харахад эдгээр голын усны эрдэсжилт, хатуулаг нь ерөнхийдөө өндөр байна. Энэ районы ус нь сул шүлтлэг орчинтой (pH 7.3-8.3), органик бодис перманганатын исэлдэх чанар 0.5-8.7 мГО/дм³ дм ${ }^{3}$, ууссан нүүрсхүчлийн хий 13.8-14.5 мг/ дм $^{3}$, биоидэвхит элементүүдээс органик биш фосфор 0.014-0.070 мг/дм³ ${ }^{3}$ аммоны ион 0.01-0.07 мг/дм³ , цахиурын исэл 1.081.89 мг/дм ${ }^{3}$, нийт төмөр 0.12-1.26 мг/дм³, фторын ион 0.9-1.0 мг/дм³ ${ }^{3}$ микроэлементээс зэс 0.002-0.082 мг/дм ${ }^{3}$, молибден 0.2-0.33 мг/дм ${ }^{3}$ тус тус байжээ[7].

Эрдэнэтийн уулын баяжуулах үйлдвэрийн үйл ажиллагаа явуулахаас өмнө 1975 онд Хангал голын ус нь цэнгэг (дундаж эрдэсжилт 480 мг/дм³ $)$, хатуувтар (дундаж хатуулаг нь 5.02 мг-экв/дм³), химийн бүрэлдэхүүний хувьд гидрокарбонатын ион зонхилж анионы харьцаа $\mathrm{HCO}_{3}{ }^{-}>\mathrm{Cl}^{-}>\mathrm{SO}_{4}{ }^{2-}$, катионы харьцаа $\mathrm{Ca}^{2+}>\mathrm{Na}^{+}+\mathrm{K}^{+}>\mathrm{Mg}^{2+}$ байсан байна.

Геоэкологийн хүрээлэнгийн судлаач- дын хийсэн судалгаагаар Эрдэнэт голын ус харьцангуй их эрдэсжилттэй (дундаж эрдэсжилт 730 мг/дм³ ${ }^{3}$, хатуу (дундаж хатуулаг нь 7.20 мг-экв/дм³ ${ }^{3}$, бохирдолттой $\left(\mathrm{NO}_{2}^{-} 0.3\right.$ мг/дм $\left.{ }^{3}\right)$, химийн бүрэлдэхүүний хувьд сульфатын ион давамгайлах ба ионы бүтцээр бичвэл анионы харьцаа $\mathrm{SO}_{4}^{2-}>\mathrm{HCO}_{3}^{-}>\mathrm{Cl}^{-}$, катионы харьцаа $\mathrm{Ca}^{2+}>$ $\mathrm{Mg}^{2+}>\mathrm{Na}^{+}+\mathrm{K}^{+}$байна. Эрдэнэт голын усыг гадаргын усны цэврийн зэргийн ангиллын нормтой харьцуулахад “их бохирдолттой" гэсэн ангид орж байна. Уулын баяжуулах Эрдэнэт үйлдвэрийн хаягдлын улмаас Зуны гол нь үндсэндээ байхгүй болжээ. Сүүлийн жилүүдийн судалгаагаар Хангал голын усны эрдэсжилт нь тогтмол өндөр буюу 600-800 мг/дм³ ${ }^{3}$ хатуулаг нь 6.50-7.50 мг-экв/дм ${ }^{3}$ [5], азотот нэгдлүүд болон зэс, никель зэрэг хүнд металлаар бохирдсон, химийн бүрэлдэхүүний хувьд сульфатын ион давамгайлах ба ионы бүтцээр бичвэл анионы харьцаа $\mathrm{SO}_{4}^{2-}>\mathrm{HCO}_{3}^{-}>\mathrm{Cl}^{-}$, катионы харьцаа $\mathrm{Ca}^{2+}>\mathrm{Mg}^{2+}>\mathrm{Na}^{+}+\mathrm{K}^{+}$, Орхон голд цутгадаг голуудаас Хангал гол ганцаараа 3-р төрлийн устай байна.

Эрдэнэт хот орчимд байрлалтай үйлдвэр, уурхайн үйл ажиллагааны улмаас Хангал голын ус бохирдож, энгийн нүдээр харсан ч янз бүрийн өнгөөр урсдаг ба шинжилгээгээр маш их бохирдолттой гарч байна.

Орхон голын адаг хэсэгт цутгадаг голуудын усны химийн бүрэлдэхүүн нь гидрокарбонатын ангийн, кальцийн болон кальц-натрийн бүлгийн 1-2-p төрлийн, чанарын хувьд Ерөө голын ус нэн цэнгэг, маш зөөлөн бусад гол нь цэнгэг, зөөлөн устай байна. Гэвч Ерөө голын хөндий дагуу Ерөө голын голдрилд болон түүний цутгал Ялбаг, Могой, Цамхаг, Их Харганат, Их Ажир, Бага Ажир, Бугант, Нарийн, Толгойт зэрэг голуудын хөндийд олон жилийн хугацаанд алт олборлолт эрчимтэй явагдсанаас голын усанд болон ёроолын хурдаст хүнд металлын хуримтлал үүсч голын усны экосистемд сөргөөр нөлөөлж байна. Алт олборлолтоос үүссэн 
булингартай усанд хүнцэл, цайр, хөнгөн цагаан, төмөр зэрэг элементүүд коллойд байдлаар орж, урсгалынхаа дагуу ёроолын хагшаасанд сууснаас эдгээр элементүүдийн агууламж өндөр, маш их бохирдолттой байна. Түүнчлэн Хараа, Шарын гол зэрэг голуудын ёроолын хагшаас лаг шаваранд

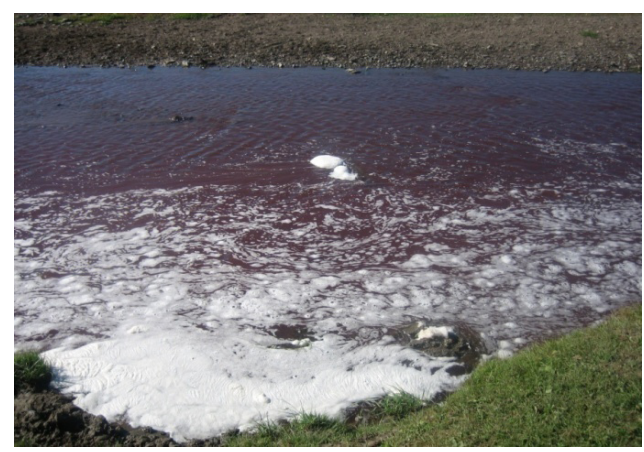

Зураг 5. Хангал гол, улаан өнгөтэй /2010.08.30/

Орхон голын хамгийн сүүлчийн цутгал гол нь Сэлэнгэ аймгийн Сүхбаатар хотын дэргэдүүр урсах Буур гол юм. Буур гол нь Сүхбаатар сумын төвийн гэр хорооллын айлуудын дундуур урсахдаа органик болон ахуйн бохирдлын улмаас "маш их бохирдолттой” гэсэн ангид орж байгаагийн гадна харьцангуй их эрдэсжилт, хатуулагтай (эрдэсжилт 600-800 мг/дм³ хатуулаг нь 6.507.50 мг-экв/дм³ ) байна. 2010 оны 08 сарын 28-ны өдрийн судалгаагаар Буур голын усны чанар, найрлагад төдийлөн өөрчлөлт гараагүй бохирдолттой хэвээрээ, аммоны ионы агууламж $\mathrm{NH}_{4}^{+} 0.7 \mathrm{мг} /$ дм$^{3}$, органик гаралтай бохирдолт болох перманганатын исэлдэх чанар 13,4 мг/дм³ ${ }^{3}$ ГУЦЗАН-оор “маш их бохирдолттой”, кальц, магнийн ион нэмэгдэж хатуу (хатуулаг нь 7.10 мг-экв/л) устай болсон байна. Түүнчлэн Сүхбаатар хотын Алтан булаг сумын төвийн дундуур урсах Хиагт гол ОХУ-ын хилээр дамжин орж ирэхдээ “маш их бохирдолттой” байдаг ба энэ нь Буур голын усны чанарт тодорхой хэмжээгээр нөлөөлөх магадлалтай. эдгээр элементүүдийн агууламж харьцангуй их байсны гадна Орхон голын урсгалын дагуух ёроолын хагшаасанд дээрх хүнд элементүүдийн агууламж өндөр байгаа нь Орхон гол хүнд металлаар бохирдсон гэсэн дүгнэлтэнд хүрч болохоор байна[2].

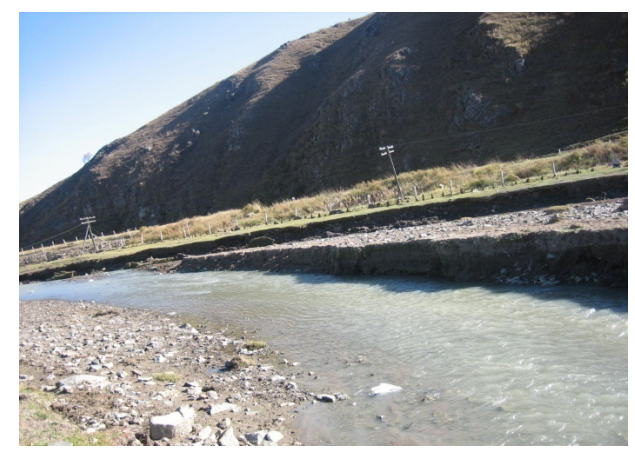

Зураг 6. Хангал гол, саарал өнгөтэй /2012.09.27/

\section{ДҮГНЭЛТ, САНАЛ}

Орхон гол нь манай орны 4 аймгийн нутгийн дамнан урсдаг хамгийн урт бөгөөд цэнгэг устай гол юм. Судалгаагаар Орхон голын адаг хэсгийн цутгал голууд нь хот тосгодын болоод уул уурхайн үйл ажиллагаанд хамгийн их өртсөний улмаас нилээд бохирдсон нь тогтоогдоод байна.

Орхон голын адаг хэсгийн голуудаас Орхон голын усны чанарт сөргөөр нөлөөлжбайгаахамгийнихбохирдолттой нь Хангал гол бөгөөд голын усны бохирдол жил ирэх тусам нэмэгдэх хандлага ажиглагдсан. Иймд Хангал гол дээр усны чанарын мониторингийн хяналтын багаж байрлуулж, бохирдлыг цаг тутамд хэмждэг болсноор цаашид холбогдох арга хэмжээг цаг алдахгүй авах боломж бүрдэнэ.

○ Орхон голын адаг хэсгийн баруун гарын цутгал болох Хэнтийн нурууны салбар уулсаас эх авсан Хараа, Шарын гол, Ерөө голууд алтны үйлдвэрлэлийн нөлөөнд өртөж булингартан, хүнд металлаар бохирдсон, Буур гол ахуйн бохирдлоор 
бохирдсон зэргээс Орхон голын усны чанарт сөрөг нөлөөтэй байна. Ерөө голын ус нь хамгийн цэнгэг, маш зөөлөн устай боловч түүний голдрил дагууд болон цутгал голуудын хөндийд алтны үйлдвэрлэл төвлөрсөн шинжтэй үйл ажиллагаа явуулж байгаатай холбоотойгоор хүнд металлаар илүү их бохирдсон ба энэ нь ёроолын хагшааст тунаж үлддэг байна. Иймд голын сав газарт байгаа уул уурхайн замбараагүй үйл ажиллагааг хуулийн дагуу зогсоож, хяналт шалгалтыг сайжруулах, нөхөн сэргээлтийг стандартын дагуу хийлгэх шаардлагатай.

Хэдийгээр Орхон голын ус бохирдож байгаa боловч голын усны эрдэсжилт, хатуулаг болон үндсэн элементүүдийн агууламж нь олон жилийн хугацаанд онцгой өөрчлөгдөөгүй, булингар нь урсгалынхаа явцад ёроолын хагшааст тунаж, голын ус өөрөө өөрийгөө цэвэршүүлж, харьцангуй цэвэр ус Сэлэнгэ мөрөнд нийлж байна.

Цаашид голын усны чанарын судалгааг хийхдээ хүнд металлын агууламжийг усанд болон ёроолын хагшааст тодорхойлж, хоруу чанар нь голын экосистем, загас жараахай болон усны амьтан, ургамалд, цаашлаад хүн малд хэрхэн нөлөөлөхийг шинжлэх ухааны үндэслэлтэй нарийвчлан судлах, нэгэнт үүссэн хүнд металлын хуримтлалыг бууруулан сөрөг нөлөөг багасгах талаар цаашид авч хэрэгжүүлэх арга хэмжээний үндэслэлийг боловсруулах ажлыг үе шаттай зохион байгуулах нь зүйтэй.

\section{Ашигласан бүтээлийн жагсаалт}

[1]. Геоэкологийн хүрээлэн. “Томоохон голуудын ай савын усны нөөц, усан орчны экологийн судалгаа" сэдэвт ажлын тайлан, Улаанбаатар, 2007.

[2]. Геоэкологийн хүрээлэн "Орхон гол түүний томоохон цутгалуудын ус, усан орчны экологийн судалгаа” сэдэвт ажлын тайлан. Улаанбаатар, 2011

[3]. Жавзан Ч., бусад “Орхон голын эх орчмын усны химийн бүрэлдэхүүн” Монгол орны геоэкологийн зарим асуудал. Улаанбаатар, 2006.

[4]. Жавзан Ч., Эрдэнэцэцэг Ц. “Орхон гол түүний томоохон цутгалуудын усны чанар, бохирдлын судалгааны дүнгээс" Монгол орны геоэкологийн асуудал. Улаанбаатар, 2010.

[5]. Жавзан Ч. “Орхон голын сав газрын гидрохими” Улаанбаатар, 2011

[6]. Жадамбаа Н., Жавзан Ч., Удвалцэцэг Г., бусад “Уул уурхайн үйл ажиллагааны улмаас байгаль орчинд үзүүлж буй сөрөг нөлөөллийн судалгаа" УИХ-ын даалгаварт ажлын тайлан. Улаанбаатар, 2005 .

[7]. Мөнгөнцэцэг А. “Сэлэнгэ мөрний гидрохими” Улаанбаатар, 2006.

[8]. Эрдэнэбаяр Я., “Орхон голын усны химийн найрлага, чанар” илтгэл. БОХТЛ, Улаанбаатар, 2011.

[9]. Operational hydrology report № 7 // Manual on sediment management and measurement. The Netherland. 2001 